OPEN ACCESS

Edited by:

Jianbo Xiao,

University of Macau, Macau

Reviewed by:

$\mathrm{Hu} \mathrm{Hou}$,

Ocean University of China, China

Lin Lin,

Hefei University of Technology, China

*Correspondence:

Yongliang Zhuang

ylzhuang@kmust.edu.cn

Specialty section:

This article was submitted to

Ethnopharmacology,

a section of the journal

Frontiers in Pharmacology

Received: 30 January 2017 Accepted: 21 February 2017

Published: 09 March 2017

Citation:

Sun L, Guo $Y$, Zhang $Y$ and Zhuang Y (2017) Antioxidant and Anti-tyrosinase Activities of Phenolic Extracts from Rape Bee Pollen and Inhibitory Melanogenesis by cAMP/MITF/TYR Pathway in B16

Mouse Melanoma Cells.

Front. Pharmacol. 8:104.

doi: 10.3389/fphar.2017.00104

\section{Antioxidant and Anti-tyrosinase Activities of Phenolic Extracts from Rape Bee Pollen and Inhibitory Melanogenesis by cAMP/MITF/TYR Pathway in B16 Mouse Melanoma Cells}

\author{
Liping Sun, Yan Guo, Yanxin Zhang and Yongliang Zhuang* \\ Yunnan Institute of Food Safety, Kunming University of Science and Technology, Kunming, China
}

Rape bee pollen possesses many nutritional and therapeutic properties because of its abundant nutrimental and bioactive components. In this study, free (FPE) and bound (BPE) phenolic extracts of rape bee pollen were obtained, phenolic and flavonoid contents were determined, and composition of phenolic acids was analyzed. In vitro antioxidant and anti-tyrosinase (TYR) activities of FPE and BPE were compared, and inhibitory melanogenesis of FPE was further evaluated. Results showed FPE and BPE contain total phenolic contents of 11.76 and $0.81 \mathrm{mg}$ gallic acid equivalents $/ \mathrm{g}$ dry weight (DW) and total flavonoid contents of 19.24 and $3.65 \mathrm{mg}$ rutin equivalents/g DW, respectively. Phenolic profiling showed FPE and BPE fractions contained 12 and 9 phenolic acids, respectively. FPE contained the highest rutin content of $774.87 \mu \mathrm{g} / \mathrm{g}$. FPE and BPE showed the high antioxidant properties in vitro and high inhibitory activities for mushroom TYR. Higher activities of FPE than those of BPE can be attributed to difference in their phenolic compositions. Inhibitory melanogenesis activities of FPE against B16 were further evaluated. Results showed suppressed intracellular TYR activity, reduced melanin content, and promoted glutathione synthesis $(p<0.05)$ in FPE-treated cells. FPE reduced mRNA expression of TYR, TYR-related protein (TRP)-1 and TRP-2, and significantly suppressed cyclic adenosine monophosphate (CAMP) levels through down-regulation of melanocortin 1 receptor gene expression $(p<0.05)$. FPE reduced mRNA expression of microphthalmia-associated transcription factor (MITF), significantly inhibiting intracellular melanin synthesis $(p<0.05)$. Hence, FPE regulates melanogenesis of B16 cells involved in CAMP/MITF/TYR pathway. These results revealed that FPE can be used as pharmaceutical agents and cosmetics to protect cells from abnormal melanogenesis.

Keywords: rape bee pollen, phenolic composition, antioxidant properties, tyrosinase activity, glutathione synthesis, mRNA expression, cAMP 


\section{INTRODUCTION}

Bee pollen is a compound of floral pollen mixed with nectar and bee secretions, and contains carbohydrates, proteins, lipids, minerals, fibers, vitamins, and amino acids (Morais et al., 2011). Bee pollen is also rich in phytochemicals, such as phenolic compounds and particularly flavonoids (Mãrghitaş et al., 2009). Bee pollen presents many nutritional and therapeutic properties because of its abundant nutriments and bioactive components. Bee pollen is used as a health food as medicine, as officially recognized by the Pharmacopoeia Committee of the People's Republic of China. Some studied showed that bee pollen improves the cardiovascular system, enhances body immunity, prevents prostate degeneration, maintains digestive system, and delays aging (Dong et al., 2015). During ancient times in China, bee pollen was used for skin whitening and beauty; however, only few studies reported this matter.

Phenolics recently received much attention for its wide range of different function, including antioxidant (Khatun et al., 2016; Xiao et al., 2016), anti-aging (Zhuang et al., 2017), antimicrobial (Alkan and Yemenicioğlu, 2016), anti-diabetic (Xiao and Högger, 2015; Xiao et al., 2015), anti-hyperlipidemia (Sarma et al., 2016), hepatoprotective (Ma et al., 2015), and anti-inflammatory effects (Xiao, 2015). In addition, several researchers have reported the anti-tyrosinase and melanogenesis-inhibitory activities of various phenolic resources, including soybean (Shukla et al., 2016), Ornithogalum narbonense (Zengin et al., 2015), Mentha (Fatiha et al., 2015), and wild edible mushroom (Kaewnarin et al., 2016). Antioxidant activity of phenolics is mainly due to their redox properties hydrogen donors, and single-oxygen quenchers. Some studies reported that different phenolics present different activities, which are directly related with phenolic profiles. Bee pollen possesses wide range of phenolic compounds, such as rutin, quercetin, vanillic acid, and protocatechuic acid (Chu et al., 2007). However, bee pollen composition varies because of its botanical and geographic origins as well as other factors, such as soil type, weather conditions, and beekeeper activities (Feás et al., 2012).

Melanin is the main component responsible for skin disorders, such as agingspots, freckles, melisma, and malignant melanoma. Biosynthesis of melanin involves a series of complex oxidative and enzymatic reactions; tyrosinase (TYR) is one of the most important enzymes for melanin biosynthesis (Demirkiran et al., 2013). Antioxidant and TYR inhibitory activities are often selected as indicator of anti-melanogenesis. Many skin whitening agents pose anti-melanogenic effects through antioxidant activity and direct inhibitory effects on TYR activity or regulation of TYR expression. Previous studies showed that B16 mouse melanoma cell can be used to evaluate inhibitory melanogenic activities. Intracellular microphthalmia-associated transcription factor (MITF) is a key transcription regulator of genes responsible for melanin biosynthesis. MITF is also involved in regulation of melanocyte differentiation, pigmentation, proliferation, and survival. An important pathway involving MITF regulates production of melanin. Melanocortin 1 receptor (MC1R) increases levels of cyclic adenosine monophosphate (cAMP). Increasing cAMP induces transcription of MITF, which subsequently up-regulates expression of genes encoding for melanogenic enzymes, including TYR-related protein (TRP)1 and TRP-2. This phenomenon thereby promotes melanin synthesis.

Rape plant is a vitally important economic crop in the world with high yields found in China. Rape bee pollen is used as nutritional food and traditional medicine with antiinflammatory, antioxidant, anti-allergic, and cardioprotective activities (Lv et al., 2015). However, phenolic characteristics and anti-melanogenic functions of rape bee pollen in China are poorly understood. Therefore, free (FPE) and bound (BPE) phenolic extracts of rape bee pollen were prepared in this study. The present work determined phenolic contents and compositions as well as antioxidant and mushroom TYR inhibitory activities in vitro. Biological activity against B16 cell was evaluated. This study increases economic value of rape bee pollen.

\section{MATERIALS AND METHODS}

\section{Chemical and Reagents}

The rape bee pollen was provided by the Sericulture and Apiculture Research Institute, Yunnan Academy of Agricultural Sciences (Mengzi, China). ABTS (2,2'-azino-bis-3ethylbenzothiazoline-6-sulphonic acid), DPPH (2,2-diphenyl-1picrylhydrazyl), TPTZ(2,4,6-tri-2-pyridinyl-1,3,5-triazine) and mushroom tyrosinase were obtained from Sigma-Aldrich Chemical Co. (St. Louis, MO, USA). Fetal bovine serum (FBS) was obtained from Sciencell Research Laboratories (San Diego, CA, USA). Dimethyl sulfoxide (DMSO), (4, 5-dimethylthiazol2-yl)-2, 5-diphenyl tetrazolium bromide (MTT), trypsin-EDTA, Pen Strep solution (Penicillin 10000 units/mL and Streptomycin $10000 \mathrm{mg} / \mathrm{mL}$ ) were purchased from Solarbio Co. (Beijing, China). Dulbecco's Modified Eagle Medium (DMEM) + GlutaMAXTM-I, Phosphate buffered saline (PBS) were purchased from Gibco Invitrogen (Thermo Fisher, USA). Acetonitrile and methanol used were HPLC grade, and other chemicals and solvents were of analytical grade.

\section{Extraction of Phenolics}

Free phenolic extract and BPE of rape bee pollen were prepared. FPE of pollen was extracted per a previously described method with some modifications (Nardini and Ghiselli, 2004). Lipids from samples (2g) were removed with hexanes, and subsequently extracted with $100 \mathrm{~mL}$ of $70 \%$ methanol by ultrasound for $60 \mathrm{~min}$. Extract was homogenized using a TGL-20B homogenizer at $4,000 \mathrm{rpm}$ for $15 \mathrm{~min}$. Supernatants were diluted twice with water and acidified to $\mathrm{pH} 2$ with $2 \mathrm{M} \mathrm{HCl}$. Extract was then extracted four times with ethyl acetate. Ethyl acetate supernatants were pooled and $10 \mathrm{~g} \mathrm{Na}_{2} \mathrm{SO}_{4}$ was added afterward, Sample was then filtered and evaporated at $45^{\circ} \mathrm{C}$ to reach a dry state. FPE were reconstituted with methanol for analysis.

Pollen extraction of BPE was conducted based on a previous study (Wang et al., 2011). Residue from free phenolics extraction was hydrolyzed with $100 \mathrm{~mL}$ of $2 \mathrm{M} \mathrm{NaOH}$ at room temperature for $1 \mathrm{~h}$ with continuous shaking under nitrogen gas. Extract was homogenized using a TGL-20B homogenizer at 4,000 rpm for 
$15 \mathrm{~min}$. Supernatants were diluted twice with water and acidified to $\mathrm{pH} 2$ with $2 \mathrm{M} \mathrm{HCl}$. Extract was then extracted four times with ethyl acetate. Ethyl acetate supernatants were pooled and $10 \mathrm{~g}$ $\mathrm{Na}_{2} \mathrm{SO}_{4}$ was added afterward. Sample was filtered and evaporated at $45^{\circ} \mathrm{C}$ to reach a dry state. BPE was reconstituted with methanol for analysis.

\section{Determination of Total Phenolic Contents}

Total phenolic contents were analyzed by the Folin-Ciocalteu (FC) colorimetric method (Moreira et al., 2008) with slight modifications. Briefly, $0.5 \mathrm{~mL}$ extract was allowed to react with $2.5 \mathrm{~mL}$ of $10 \% \mathrm{FC}$ reagent for $5 \mathrm{~min}$, and $2 \mathrm{~mL}$ of $7.5 \%$ aqueous sodium carbonate solution was subsequently added. Reaction in mixture lasted for $60 \mathrm{~min}$ at room temperature in the dark. Absorbance was detected at $765 \mathrm{~nm}$ using a TU-1901 spectrometer (Persee Inc., Beijing, China) with gallic acid as standard. Total phenolic content was expressed as mg gallic acid equivalents (GAE) per $1 \mathrm{~g}$ dry weight (DW) of samples.

\section{Determination of Total Flavonoids Content}

Total flavonoid contents were determined by $\mathrm{NaNO}_{2}-\mathrm{Al}\left(\mathrm{NO}_{3}\right)_{3}$ method. Extract was mixed with $0.3 \mathrm{~mL} 5 \% \mathrm{NaNO}_{2}$ solution for $6 \mathrm{~min}$ followed by addition of $0.3 \mathrm{~mL} 10 \% \mathrm{Al}\left(\mathrm{NO}_{3}\right)_{3}$ solution for $6 \mathrm{~min} .4 \mathrm{~mL}$ of $1 \mathrm{M} \mathrm{NaOH}$ solution was then added to the reaction mixture. Ethanol was incorporated to obtain $10 \mathrm{~mL}$ total volume. Absorbance was determined at $510 \mathrm{~nm}$ using rutin as standard. Total flavonoid content was expressed as $\mathrm{mg}$ rutin equivalents (RE) per $1 \mathrm{~g} \mathrm{DW}$ of sample.

\section{Determination of Phenolic Composition}

High performance liquid chromatography (Agilent 1000, Agilent Technologies, Santa Clara, CA, USA) of phenolic compounds was performed on a reverse-phase Zorbax SB-C18 column (4.6 $\mathrm{mm} \times 250 \mathrm{~mm}, 5$-micron), using a gradient program with two solvent systems (A, $0.1 \%$ acetic acid in water; $\mathrm{B}, 0.1 \%$ acetic acid in acetonitrile). The initial condition was $8 \% \mathrm{~B}$; it was changed to $10 \% \mathrm{~B}(0-2 \mathrm{~min})$; to $30 \% \mathrm{~B}(2-27 \mathrm{~min})$, to $90 \% \mathrm{~B}(27-50 \mathrm{~min})$, to $100 \% \mathrm{~B}(50-51 \mathrm{~min})$, to $100 \% \mathrm{~B}(51-$ $55 \mathrm{~min})$, to $8 \% \mathrm{~B}$ (55-58 $\mathrm{min})$. Injection volume was $20 \mu \mathrm{L}$. Flow rate was $1 \mathrm{~mL} / \mathrm{min}$ and signals were detected at $280 \mathrm{~nm}$ (Sun et al., 2014). Calibration curves were plotted using five different concentrations of 12 phenolic compound standards.

\section{Antioxidant Activities In vitro DPPH Radical Scavenging Activity}

Scavenging DPPH radical activity was determined by a previously described method (Wang et al., 2012). Briefly, $0.4 \mathrm{~mL}$ of samples were allowed to react with $2 \mathrm{~mL}$ of $0.1 \mathrm{mM}$ methanolic solution of DPPH radical. The mixture was then evenly combined and allowed to stand at room temperature in the dark for $30 \mathrm{~min}$. Absorbance was measured at $517 \mathrm{~nm}$ against methanol blank. Vitamin C ( Vc) was used as a positive control. DPPH radical scavenging ability was expressed as percentage inhibition of $\mathrm{DPPH}$ radical. Inhibitory percentage was calculated using the equation below:

$$
\text { Scavenging ability }(\%)=\left(1-A_{\text {sample }} / A_{\text {blank }}\right) \times 100
$$

IC $_{50}$ value was defined as effective concentration required for scavenge $50 \%$ radical.

\section{ABTS•+-Scavenging Activity Assay}

Stock ABTS•+ solution was prepared from $7 \mathrm{mM}$ ABTS and $40 \mathrm{mM}$ of potassium persulfate in distilled water (Re et al., 1999). When used in ABTS•+ working solution, stock ABTS•+ solution was diluted with ethanol to achieve an absorbance of 0.75 at $734 \mathrm{~nm}$. Briefly, $4 \mathrm{~mL}$ of ABTS + working solution and $0.5 \mathrm{~mL}$ of sample solution of different concentrations were mixed and incubated at $30^{\circ} \mathrm{C}$ in water bath for $6 \mathrm{~min}$. Absorbance at $734 \mathrm{~nm}$ was recorded. Trolox was used as positive control. ABTS•+scavenging activity was calculated by Formula (1). $\mathrm{IC}_{50}$ value was defined as an effective concentration for scavenge $50 \%$ radical.

\section{Reducing Power Assay by Ferric Reducing Antioxidant Power (FRAP) Method}

Freshly prepared FRAP reagent contained $100 \mathrm{~mL}$ of acetate buffer (300 mM, pH 3.6), $10 \mathrm{~mL}$ of TPTZ solution (10 mM), and $10 \mathrm{~mL}$ of ferric chloride solution $(20 \mathrm{mM})$. Briefly, $4.5 \mathrm{~mL}$ of FRAP reagent and $0.15 \mathrm{~mL}$ of sample solution of different concentrations were mixed and incubated at $37^{\circ} \mathrm{C}$ in water bath for $6 \mathrm{~min}$. Absorbance at $593 \mathrm{~nm}$ was recorded. Increase in A593 represents reducing power (Benzie and Strain, 1996). Vc was used as positive control. $\mathrm{EC}_{50}$ was defined as effective mixture concentration that produces 0.500 absorbance units.

\section{Determination of Inhibitory Activity for Mushroom TYR}

Distilled water was added to different concentrations of samples to reach $1 \mathrm{~mL}$ volume. After $5 \mathrm{~min}$ of incubation at room temperature, $3 \mathrm{~mL}$ of L-tyrosine was mixed and incubated for $15 \mathrm{~min}$ at $37^{\circ} \mathrm{C}$. Afterward, $0.1 \mathrm{~mL}$ of mushroom TYR solution was added and incubated for $25 \mathrm{~min}$ at $37^{\circ} \mathrm{C}$. Absorbance was measured at $470 \mathrm{~nm}$ against blank without TYR. Percentage inhibition of enzyme activity and $\mathrm{IC}_{50}$ values were calculated according to the following equation:

$$
\text { Inhibition }(\%)=\left(A_{0}-A_{1}+A_{2}\right) / A_{0} \times 100
$$

where $A_{0}, A_{1}$, and $A_{2}$ are absorbance values of control, samples, and blank, respectively.

\section{Cell Culture and Determination of Intracellular activity Cell Culture}

B16 mouse melanoma cells were purchased from the Kunming Institute of Zoology of the Chinese Academy of Sciences (Kunming, China). The B16 melanoma cells were cultured in high glucose-DMEM, and then supplemented with 10\% FBS, $100 \mathrm{mg} / \mathrm{mL}$ streptomycin and $100 \mathrm{U} / \mathrm{mL}$ penicillin. Cells were maintained in a humidified incubator with $5 \% \mathrm{CO}_{2}$ at $37^{\circ} \mathrm{C}$, and were sub-cultured every 2 days to maintain logarithmic growth. 


\section{Cell Viability}

B16 melanoma cell viability was assessed using a previously described method with slight modification (Souza et al., 2012). Cells $\left(1.0 \times 10^{4}\right.$ cells, $200 / \mu \mathrm{L} \cdot$ well $)$ were seeded into 96-well microplates. After $24 \mathrm{~h}$ of incubation, different concentrations $(0,20,60$, and $100 \mu \mathrm{g} / \mathrm{mL})$ of samples, along with $200 \mathrm{nM}$ $\alpha$-melanocyte stimulating hormone $(\alpha-\mathrm{MSH})$, were added to each well of plates. After incubating plates for additional $24 \mathrm{~h}$ and $48 \mathrm{~h}$, attached cells were incubated with MTT $(0.5 \mathrm{mg} / \mathrm{mL}, 4 \mathrm{~h})$ and subsequently solubilized in DMSO. Absorbance at $570 \mathrm{~nm}$ was then measured using a micro-plate reader (SpectraMax M5 Multi-Mode Microplate Reader, Molecular Devices, Sunnyvale, CA, USA) to calculate percentage of cell viability.

\section{Measurement of Melanin Contents}

Melanin content was measured referring to a previously described method with slight modification (Tsuboi and Kondoh, 1998). B16 cells $\left(2 \times 10^{5}\right.$ cell/well $)$ were grown in six-well plates. With different concentration samples and $200 \mathrm{nM} \alpha$-MSH added for $48 \mathrm{~h}$, cells were dissolved in $1 \mathrm{~mL}$ of $1 \mathrm{M} \mathrm{NaOH}$ (containing $10 \%$ DMSO) by ultrasound for $30 \mathrm{~min}$, incubated $\left(90^{\circ} \mathrm{C}\right)$ in water bath for $2 \mathrm{~h}$, and centrifuged for $15 \mathrm{~min}$ at 3,000 rpm. Optical densities (OD) of supernatants were measured at $450 \mathrm{~nm}$ using an ELISA reader. Intracellular protein content was measured by BCA method. Relative melanin content was calculated using the following equation:

$$
\text { Melanin relative contents }(\%)=\mathrm{OD}_{1} / \mathrm{OD}_{0} \times 100
$$

The results were fixing by protein content. $\mathrm{OD}_{0}$ and $\mathrm{OD}_{1}$ were ODs of control and samples, respectively.

\section{TYR Activity Assay}

Activity assay for intracellular TYR was performed using a previously described method (Tomita, 1992). B16 melanoma cells $\left(2 \times 10^{5}\right.$ cells/well $)$ were incubated in six-well plates with different sample concentrations and $200 \mathrm{nM} \alpha-\mathrm{MSH}$. Cells were washed twice with PBS (0.1 M, pH 6.8), freeze-thaw lysed in $300 \mu \mathrm{L}$ of $0.1 \mathrm{M}$ PBS containing 5\% Triton X-100 and ultrasoundlysed in a ice-water bath. Briefly, $200 \mu \mathrm{L}$ of supernatants were incubated at $37^{\circ} \mathrm{C}$ for $10 \mathrm{~min}$ and then mixed with $50 \mu \mathrm{L}$ of $0.1 \%$ L-DOPA in PBS (0.1 M, pH 6.8). Spectrophotometric analysis was performed at $475 \mathrm{~nm}$ for $0 \mathrm{~min}$ and $30 \mathrm{~min}$; content of protein was measured by BCA method. TYR-related activity was calculated using the following equation:

$$
\text { TYR relative activity }(\%)=\left(A_{30}^{\prime}-A_{0}^{\prime}\right) /\left(A_{30}-A_{0}\right) \times 100
$$

Results were fixed by protein content. $A_{0}^{\prime}, A_{30}^{\prime}$ represent absorbance values of samples at 0 and $30 \mathrm{~min}$, respectively, where as $A_{0}$ and $A_{30}$ are absorbance values of control at 0 and $30 \mathrm{~min}$, respectively.

\section{Ratio of Glutathione and Glutathione Disulfide (GSH/GSSG) Assay}

Glutathione and glutathione disulfide ratio was determined using the corresponding kits (NanJing JianCheng Bio Institute,
Nanjing, China). GSH content was determined following formation of yellow-colored 5-thio-2-nitrobenzoic acid (TNB), which is produced by reaction between GSH and 5, 5'dithiobis-2-nitrobenzoic acid (DTNB). GSSG was measured according to DTNB-glutathione reductase recycling assay (Hou et al., 2011). Total protein content was measured according to BCA method, and all results were fixed by protein content.

\section{Determination of Intracellular cAMP Levels}

B16 melanoma cells were treated similar to the TYR activity assay. Intracellular cAMP levels were measured using an I 125 kit (Shanghai University of Chinese Traditional Medicine, Shanghai, China) following manufacturer's instructions.

\section{Measurement of mRNA Expression by Quantitative Reverse Transcription-Polymerase Chain Reaction (qRT-PCR)}

B16 cells $\left(8 \times 10^{4}\right.$ cells/well) were cultured in $2 \mathrm{~mL}$ of six-well plate for $24 \mathrm{~h}$. After treatment with different concentrations of FPE and $\alpha$-MSH $(200 \mathrm{nM})$ for $48 \mathrm{~h}$, cells were washed with cold PBS. Total RNA was extracted by Trizol. RT was conducted by PrimeScript ${ }^{\mathrm{TM}}$ RT reagent Kit with gDNA Eraser (Perfect Real Time) (TaKaRa Biotechnology, Dalian, China) following manufacturer's instructions. cDNA was amplified on StepOnePlus Real-Time PCR System (Applied Biosystems, Foster City, CA, USA) using SYBR ${ }^{\circledR}$ Premix Ex Taq ${ }^{T M}$ II (Tli RNaseH Plus) (TaKaRa Biotechnology, Dalian, China) and corresponding probes (Shenggong, Shanghai, China). Real-time qPCR analysis was conducted under the following temperatures and times: initial denaturation at $95^{\circ} \mathrm{C}$ for $30 \mathrm{~s}$ and 40 cycles of denaturation at $95^{\circ} \mathrm{C}$ for $5 \mathrm{~s}$ and annealing at $60^{\circ} \mathrm{C}$ for $30 \mathrm{~s}$. Relative expression level of each melanogenic protein mRNA was normalized to $\beta$-actin mRNA. Primers refer to the following previously reported primer sequences as follows: For $\beta$-actin, $5^{\prime}$-ACTA TTGGCAACGAGCGGTT-3' (forward) and $5^{\prime}$-ATGGATG CCACAGGATT-CCA-3' (reverse); for TYR, 5'-GTCGT ACCCT GAAAATCCTAACT-3' (forward) and $5^{\prime}$-CATCG-CATAAAACC TGATGGC3'(reverse); for TRP-1, 5' -CTTTCTCCCTTCCTTAC TGG-3' (forward) and 5'-TCGTACTCTTCCAAGGATTCA$3^{\prime}$ (reverse); for TRP-2, 5' -TTATATCCTTCGAAA-CCAGGA-3' (forward) and GGGAAT-GGATATTCCGTCTTA-3' (reverse); for MITF, 5'-GTATGAACACGCACTCTCGA-3' (forward) and 5'-GTAACGTATTTGCCATTTGC-3' (reverse) (Kwak et al., 2011); for MC1R, 5'-TGACCTGATGGTAAGTGTCAGC-3' (forward) 5'-ATGAGCACGTCAATGAGGTT-3' (reverse) (Chang et al., 2015).

\section{Statistical Analyses}

Data were expressed as means \pm standard deviation, and were tested using SPSS (Version 20.0, SPSS Inc., Chicago, IL, USA). Differences at $p<0.05$ were considered significant. 


\section{RESULTS AND DISCUSSION}

\section{Total Phenolic and Flavonoid Contents}

In this study, FPE and BPE were obtained. As shown in Table 1, FPE and BPE of rape bee pollen were 11.76 and $0.81 \mathrm{mg} \mathrm{GAE} / \mathrm{g}$ DW, respectively. FPE comprised a large percentage (93.5\%) of total phenolic content. Our result was higher than that of Žilić et al. (2014), who reported that in different genotypes of maize pollen, total phenolics were within 7.78-9.93 mg GAE/g DW. Total flavonoid content was $19.24 \mathrm{mg}$ RE/g DW, which was higher than that of maize pollen (Žilić et al., 2014). Free flavonoid content also accounted for large percentage $(84.1 \%)$ of total flavonoid in rape bee pollen.

\section{Phenolic Compositions}

As shown in Table 2, 12 and 9 phenolic acids were found in FPE and BPE, respectively. FPE contained high quantity of rutin $(774.87 \mu \mathrm{g} / \mathrm{g})$. Similar quantities of rutin were measured in bee pollen samples from Baltic region (Kaškonienë et al., 2015). Wang et al. (2012) reported that aqueous extracts of green asparagus exhibit significant antioxidant and antityrosinase activity; such extracts are rich in rutin. In rape bee pollen, quercetin content of FPE was $196.38 \mu \mathrm{g} / \mathrm{g}$, which was close to that of honeybee pollen collected in the Baltic region (Kaškonienë et al., 2015). Quercetin is a flavonoid that exhibits high antioxidant and anti- melanogenesis activities. High quantity of benzoic acid was detected in free extract (314.16 $\mu \mathrm{g} / \mathrm{g}$ ), and kaempferol content was $9.26 \mu \mathrm{g} / \mathrm{g}$; these

TABLE 1 | Determination of total phenolic and flavonoid content of rape bee pollen.

\begin{tabular}{lcc}
\hline & $\begin{array}{c}\text { Total phenolic content } \\
\text { (mg GAE/g DW) }\end{array}$ & $\begin{array}{c}\text { Total flavonoid content } \\
\text { (mg RE/g DW) }\end{array}$ \\
\hline FPE & $11.76 \pm 0.04^{\mathrm{b}}$ & $19.24 \pm 0.06^{\mathrm{b}}$ \\
$\mathrm{BPE}$ & $0.81 \pm 0.01^{\mathrm{c}}$ & $3.65 \pm 0.03^{\mathrm{c}}$ \\
Total & $12.57 \pm 0.05^{\mathrm{a}}$ & $22.89 \pm 0.09^{\mathrm{a}}$ \\
\hline
\end{tabular}

Different letters in the same column were significantly different $(p<0.05)$.

TABLE 2 | Phenolic composition of different extracts of rape bee pollen.

\begin{tabular}{lcr}
\hline Phenolic compounds & FPE $(\boldsymbol{\mu} \mathbf{g} / \mathbf{g})$ & BPE $(\boldsymbol{\mu} \mathbf{g} / \mathbf{g})$ \\
\hline Rutin & $774.87 \pm 8.77$ & $6.45 \pm 0.40$ \\
p-hydroxybenzoic acid & $84.28 \pm 5.29$ & $11.08 \pm 0.13$ \\
Benzoic acid & $314.16 \pm 11.87$ & $3.46 \pm 0.14$ \\
Resveratrol & $242.88 \pm 6.32$ & $4.39 \pm 0.13$ \\
Quercetin & $196.38 \pm 3.14$ & $\mathrm{nd}$ \\
Cinnamic acid & $102.65 \pm 3.79$ & $2.30 \pm 0.17$ \\
Vanillin & $58.41 \pm 1.22$ & $\mathrm{nd}$ \\
Kaempferol & $9.26 \pm 6.21$ & $0.17 \pm 0.18$ \\
Protocatechuic acid & $119.38 \pm 4.82$ & $\mathrm{nd}$ \\
p-coumaric acid & $32.63 \pm 2.19$ & $11.22 \pm 0.10$ \\
Gallic acid & $\operatorname{tr}$ & $\mathrm{tr}$ \\
Catechin & $\operatorname{tr}$ & $\mathrm{tr}$ \\
\hline
\end{tabular}

nd, not detected; tr, trace. values are higher than those reported of Fanali et al. (2013). Resveratrol content in FPE was $242.88 \mu \mathrm{g} / \mathrm{g}$. Our result was higher than that reported by Cheng et al. (2013), who reported Shanxi (China) bee pollen contained $177.15 \mu \mathrm{g} / \mathrm{g}$ resveratrol. Resveratrol possesses a number of beneficial effects, including anticancer, antiatherogenic, antioxidative, anti-inflammatory, anti-microbial and estrogenic activities. Cinnamic acid was found in BPE and was particularly high in FPE $(102.65 \mu \mathrm{g} / \mathrm{g})$; this amount is higher than that for some previously described pollen extracts (Kaškonienë et al., 2015). P-coumaric acid content was higher than the pollen covered (Ulusoy and Kolayli, 2014). In sum, rape bee pollen presents a wide range of variety because of its phenolic acids components, which differ from those of other pollens. Floral origin, geographical collection area, and bee species are elements responsible for imparities in qualitative and quantitative composition of bee pollen phenolic compounds.

\section{Antioxidant Activities In vitro}

Various methods were used to analyze antioxidant capacity because antioxidant agents with different compositions and contents present different mechanism for their antioxidant capacities. In the present study, we selected three models in evaluating antioxidant activities of phenolic extract of rape bee pollen in vitro, such activities include scavenging radical activity of DPPH and ABTS assays and ferric-ion-reducing capacity.

2,2-diphenyl-1- picrylhydrazyl assay is widely used in evaluating ability of antioxidant to scavenge free radicals (Shukla et al., 2016). DPPH•+-stable purple radicals react with antioxidants, generating stable diamagnetic molecule. Solutions lose their color per the number of electrons used up (Fatiha et al., 2015). As shown in Table 3, FPE showed high DPPH scavenging ability and $\mathrm{IC}_{50}$ value of $1.27 \mu \mathrm{g} / \mathrm{mL}$. FPE demonstrated better activity than BPE and Vc, suggesting that FPE are good DPPH scavengers.

In ABTS assay, blue/green ABTS $\bullet+$ chromophore is produced by reaction of ABTS and potassium persulfate. Antioxidants reduce radical of ABTS $\bullet+$ back to ABTS (Guedes et al., 2013). Phenolic extract of rape bee pollen showed high ABTS radical-scavenging activity. FPE and BPE yielded $\mathrm{IC}_{50}$ values of 3.19 and $3.85 \mu \mathrm{g} / \mathrm{mL}$, respectively (Table 3). FPE exhibited higher antioxidant capacity and significantly better than Trolox (45.88 $\mu \mathrm{g} / \mathrm{mL})$.

Ferric reducing antioxidant power assay is based on ability of antioxidant to reduce $\mathrm{Fe}^{3+}$ to $\mathrm{Fe}^{2+}$ in the presence of

TABLE 3 | Antioxidant capacity and mushroom tyrosinase inhibitory activity of rape bee pollen.

\begin{tabular}{lccc}
\hline & $\begin{array}{c}\text { DPPH IC } \\
(\mu \mathbf{g} / \mathbf{m L})\end{array}$ & $\begin{array}{c}\text { ABTS IC }_{50} \\
(\mu \mathbf{g} / \mathbf{m L})\end{array}$ & $\begin{array}{c}\text { FRAP EC } \\
(\mu \mathbf{g} / \mathbf{m L})\end{array}$ \\
\hline FPE & $1.27 \pm 0.00^{\mathrm{c}}$ & $3.19 \pm 0.06^{\mathrm{c}}$ & $0.12 \pm 0.00^{\mathrm{c}}$ \\
BPE & $3.21 \pm 0.04^{\mathrm{a}}$ & $3.85 \pm 0.02^{\mathrm{b}}$ & $2.98 \pm 0.02^{\mathrm{a}}$ \\
Positive control & $3.05 \pm 0.61^{\mathrm{b}}$ & $\begin{array}{c}45.88 \pm 0.25^{\mathrm{a}} \\
\text { (Trolox) }\end{array}$ & $\begin{array}{c}1.05 \pm 0.5^{\mathrm{b}} \\
\text { (Vc) }\end{array}$ \\
\hline
\end{tabular}

Different letters in the same column were significantly different $(p<0.05)$. 


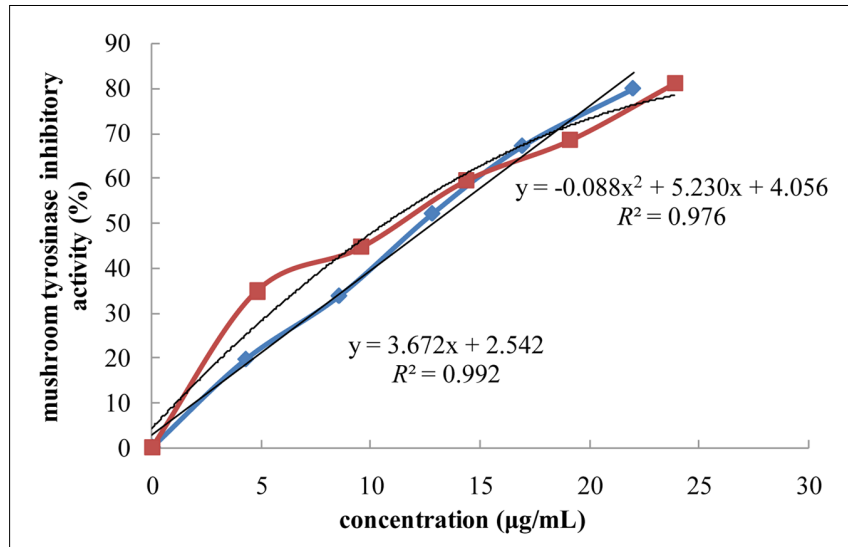

FIGURE 1 | Effect of phenolic extracts of rape bee pollen on mushroom tyrosinase inhibitory activity. $\square$ : FPE, $\diamond$ : BPE.

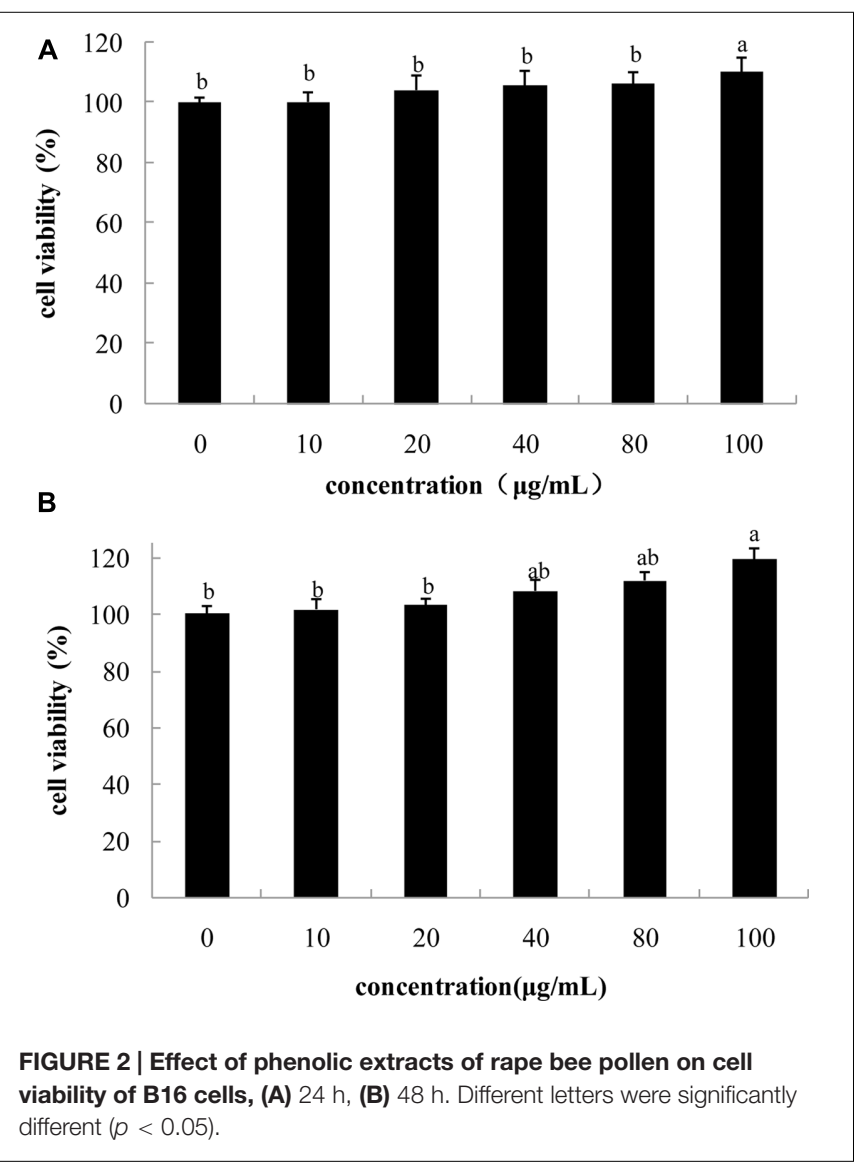

TPTZ (Zengin et al., 2015), forming an intense blue $\mathrm{Fe}^{2+}$. TPTZ complex with maximum absorption at $593 \mathrm{~nm}$. Reduced absorbance is proportional to antioxidant content. Table 3 shows results for ferric-ion-reducing activities of rape bee pollen after FRAP assay. FRAP capacity followed the sequence, FPE $>$ Vc $>$ BPE. FPE demonstrated significantly higher activity than $\mathrm{BPE}(p<0.05)$ and $\mathrm{EC}_{50}$ value of $0.12 \mu \mathrm{g} / \mathrm{mL}$. FPE of rape bee pollen presents better reducing power.

\section{Mushroom TYR Inhibitory Activity}

Tyrosinase inhibitors are clinically used for treatment of some dermatological disorders associated with melanin hyperpigmentation and for skin whitening in cosmetic. As shown in Figure 1, FPE showed highly potent inhibition against mushroom TYR activity. The following equation expresses formula for anti-tyrosinase activities (y) of FPE and its concentrations $(\mathrm{x}): y=-0.088 \mathrm{x} 2+5.230 \mathrm{x}+4.056 \mathrm{IC}_{50}$ value was calculated as $10.72 \mu \mathrm{g} / \mathrm{mL}$. Anti-tyrosinase activities and concentrations of BPE exhibited linear correlation; $R^{2}$ was 0.992 , and calculated $\mathrm{IC}_{50}$ value was $12.92 \mu \mathrm{g} / \mathrm{mL}$ (Figure 1). FPE showed higher activity than BPE. Inhibitory activity against tyrosinase was also observed for some phenolic compounds, such as quercetin, benzoic acid and their derivatives. Therefore, inhibitory tyrosinase activity of FPE and BPE is related to their phenolic profiles.

Considering in vitro antioxidant and anti-tyrosinase activities of FPE and BPE, we further evaluated the effect of FPE on antimelanogenesis in B16 mouse melanoma cells.

\section{Cell Viability}

Any potential cytotoxic effect of rape bee pollen extracts should be determined before further testing (Chang et al., 2015). Effect of FPE on viability of B16 cells was measured. As shown in Figure 2, FPE did not reduce growth of B16 melanoma cells at concentration of $0-100 \mu \mathrm{g} / \mathrm{mL}$. This result revealed that rape bee pollen extracts are non-cytotoxic to B16 cells.

\section{Intracellular Melanin Synthesis and TYR Activity in Melanocytes}

Intracellular melanin content directly reflects anti-melanogenic activity. Table 4 shows different concentrations of FPE inhibiting increase in melanin content in B16 cells. Phenolic extracts of rape pollen potently suppressed melanin production in B16 cells. FPE affects melanin content in a dose-dependent manner. Inhibitory melanin production activity increased with increasing concentrations of FPE. Intracellular melanin contents significantly decreased by $47.51 \%$ at concentration of $100 \mu \mathrm{g} / \mathrm{mL}$.

Tyrosinase is a vital enzyme for melanin synthesis, and observing its intracellular activity is constantly the first step in studying melanin synthesis (Hu et al., 2015). As shown in Table 4. FPE effectively inhibited intracellular TYR activity of B16 cells in dose-dependent manner; this inhibition is similar

TABLE 4 | Effects of free rape bee pollen extract on intracellular melanin content and tyrosinase inhibitory activity.

\begin{tabular}{lcc}
\hline Concentration $(\boldsymbol{\mu g} / \mathbf{m L})$ & $\begin{array}{c}\text { Melanin relative } \\
\text { contents (\%) }\end{array}$ & $\begin{array}{c}\text { Tyrosinase relative } \\
\text { activity (\%) }\end{array}$ \\
\hline control & $100 \pm 1.21^{a}$ & $100 \pm 3.25^{a}$ \\
20 & $84.23 \pm 2.16^{b}$ & $95.39 \pm 4.84^{a}$ \\
60 & $67.37 \pm 2.23^{c}$ & $72.49 \pm 4.17^{b}$ \\
100 & $52.49 \pm 3.06^{d}$ & $59.14 \pm 4.02^{c}$
\end{tabular}

Different letters in the same column were significantly different $(p<0.05)$ from each other. 


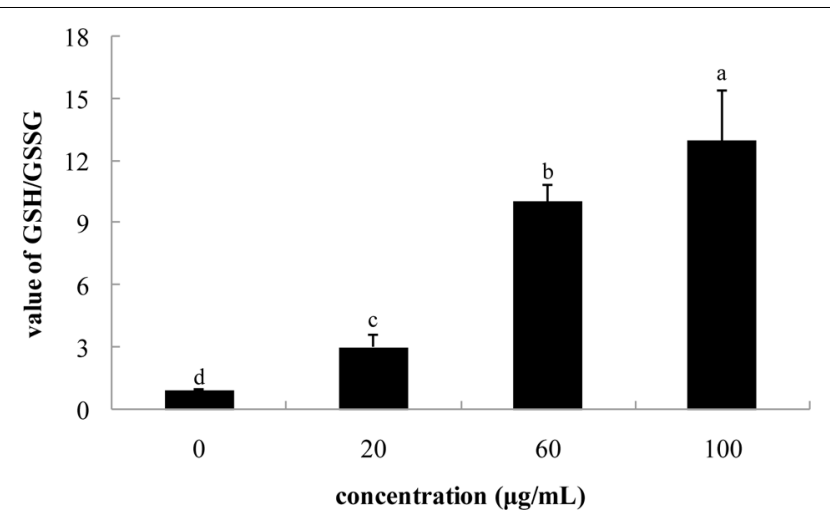

FIGURE 3 | Effect of phenolic extracts of rape bee pollen on the value of GSH/GSSG of B16 cells. Different letters were significantly different $(p<0.05)$.

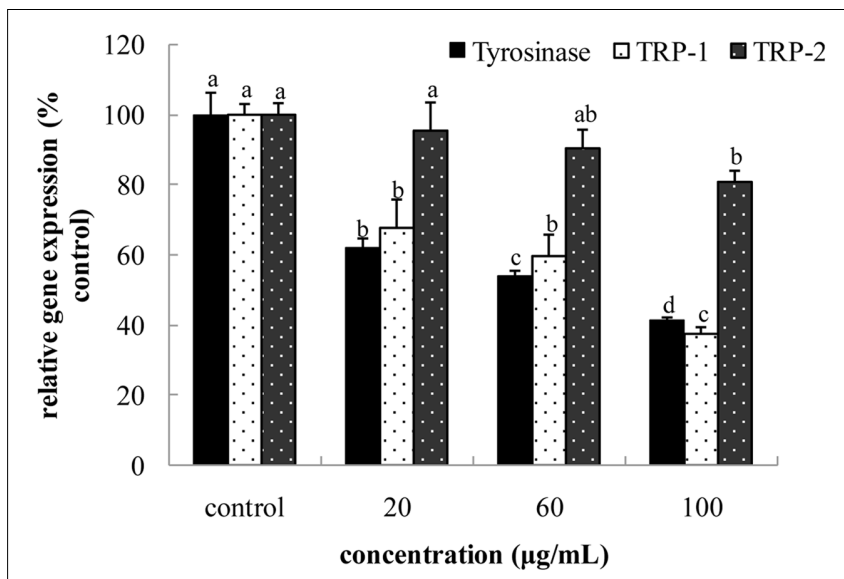

FIGURE 4 | Effect of free phenolic extract (FPE) of rape bee pollen on tyrosinase (TYR), TRP-1 and TRP-2 of B16 cells. Different letters were significantly different $(p<0.05)$ in same bar graph.

to change in melanin content. At concentration of $100 \mu \mathrm{g} / \mathrm{mL}$, FPE significantly reduced TYR activity in B16 cells by $40.86 \%$. TYR inhibitory activities of rape bee pollen extract are associated with its phenolic acids and antioxidant activities. This finding is similar to that of a previous study (Shukla et al., 2016), which reported that TYR inhibitory activity is related to hydroxyl group of phenolic compounds. This group forms hydrogen bonds with enzyme active sites to promote steric hindrance, conformational changes, and directly suppress enzymatic activity.

\section{GSH/GSSG Value}

Melanin synthesis is involved in production of several reactive oxygen species, including $\bullet \mathrm{O}^{2-}, \bullet \mathrm{OH}$, and $\mathrm{NO} \bullet$. Therefore, intracellular reducing power plays a crucial role in the regulation of melanogenesis (Zhuang et al., 2009). As an important intracellular indicator, the GSH/GSSG ratio is involved in the intracellular regulation of melanin synthesis. Figure 3 shows effects of pollen phenolic extract on intracellular GSH/GSSG ratio in B16 cells observed in this study. Phenolic extracts

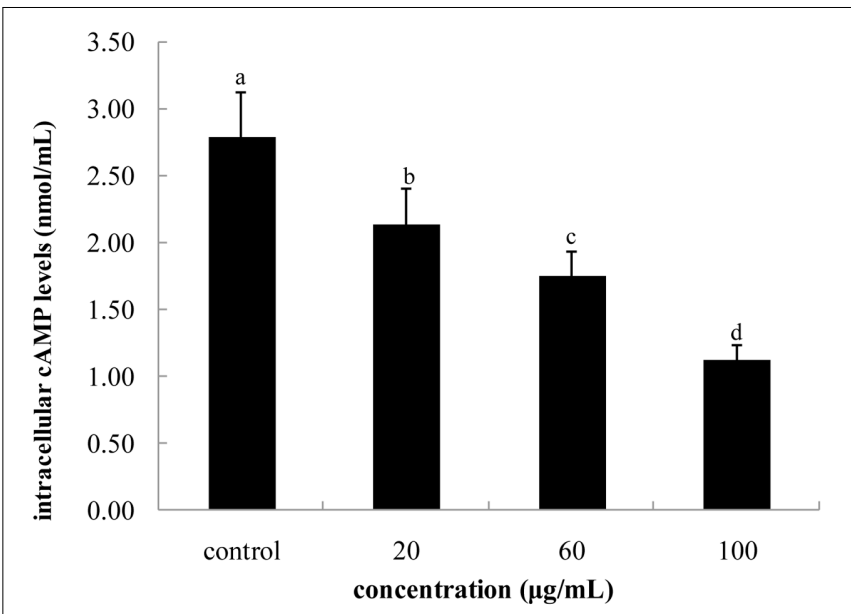

FIGURE 5 | Effect of FPE of rape bee pollen on intracellular cAMP levels of B16 cells. Different letters were significantly different $(p<0.05)$.

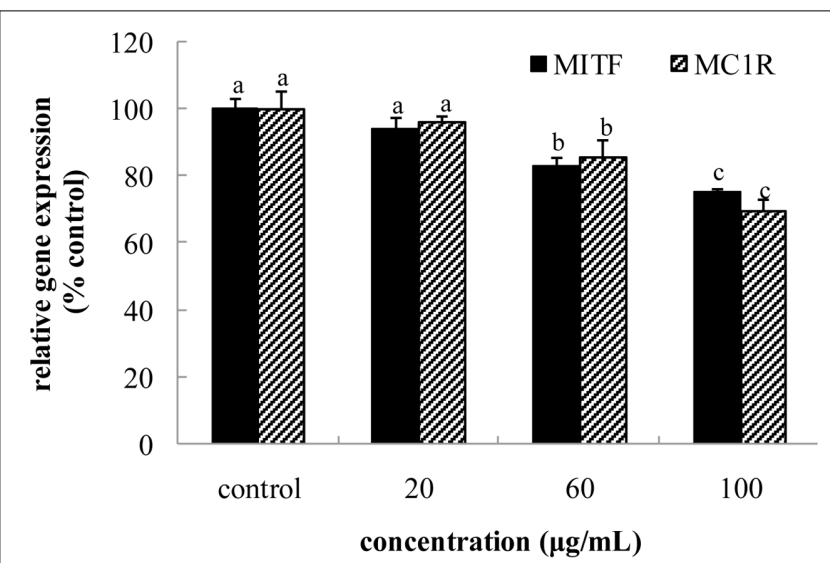

FIGURE 6 | Effect of FPE of rape bee pollen on microphthalmiaassociated transcription factor (MITF) and MC1R mRNA expression of B16 cells. Different letters were significantly different $(p<0.05)$ in same bar graph.

significantly enhanced intracellular GSH/GSSG ratio, and value of GSH/GSSG dose-dependently increased with concentration of FPE. Specifically, value of GSH/GSSG in B16 treated with FPE $(100 \mu \mathrm{g} / \mathrm{mL})$ was 13.55 times that of control group. TYR activity in $\mathrm{B} 16$ cell requires oxidative pressure. Phenolics effectively increase reducing power of B16 cell via their antioxidant activity. Therefore, phenolics of FPE indirectly inhibit intracellular activity of TYR to reduce melanin synthesis.

\section{Intracellular mRNA Expression of TYR, TRP-1 and TRP-2}

Tyrosinase, TRP-1 and TRP-2 are key enzymes involved in melanin biosynthesis. TYR catalyzes two distinct reactions, including conversion of tyrosine to L-DOPA and DOPA to dopaquinone. Dopaquinone is spontaneously converted to dopachrome. TRP-2 catalyzes conversion of dopachrome to 5, 6-dihydroxyindole-2-carboxylic acid (DHICA), whereas TRP-1 
induces oxidation of DHICA to indole-5, 6-quinone-2-carboxylic acid. As shown in Figure 4, after treatment with FPE at concentrations of 20,60, and $100 \mu \mathrm{g} / \mathrm{mL}$, TYR expression in B16 melanoma cells significantly reduced by $37.18,46.05$, and $58.47 \%$, respectively, in a dose-dependent manner. Expression levels of TRP-1 were inhibited by $32.49,40.40$, and $61.63 \%$, respectively. Compared with control, effect of $20 \mu \mathrm{g} / \mathrm{mL}$ FPE was not significantly different on TRP-2 $(p>0.05)$, and that of $100 \mu \mathrm{g} / \mathrm{mL}$ FPE was significantly lower than that of control $(p<0.05)$.

\section{Intracellular Content of CAMP and the mRNA Expression of MC1R and MIFT}

Microphthalmia-associated transcription factor regulates expression of MC1R and $\alpha-M S H$ binds to its specific MC1R, which enhances MITF expression. Expression of MC1R increases levels of CAMP, and cAMP pathway plays a key role in regulation of melanogenesis. cAMP-elevating agents enhance expression of TYR mRNA, implying requirement of cAMP for optimal melanogenic activity. As shown in Figures 5, 6, both intracellular cAMP levels and MC1R expression in FPE-treated B16 cells were down-regulated in a dose-dependent manner. Compared with control, cAMP levels and MC1R expression decreased by 59.71 and $30.62 \%$, respectively, at FPE concentration of $100 \mu \mathrm{g} / \mathrm{mL}$. Increase in cAMP level induced MITF transcription. MITF is a pivotal regulator involved in expression of melanogenic proteins. As shown in Figure 6, expression level of MITF was reduced by FPE in a dose-dependent manner. Compared with control, expressions of MITF reduced by 16.89 and $24.92 \%$ at 60 and $100 \mu \mathrm{g} / \mathrm{mL}$ FPE treatment, respectively. FPE induced significant suppressions on mRNA expression levels of TYR via MITF downregulation, which was caused by reduced intracellular cAMP levels. These results revealed that melanogenesis inhibitory mechanism of FPE is involved in cAMP/MITF/TYR pathway.

\section{REFERENCES}

Alkan, D., and Yemenicioğlu, A. (2016). Potential application of natural phenolic antimicrobials and edible film technology against bacterial plant pathogens. Food Hydrocol. 55, 1-10. doi: 10.1016/j.foodhyd.2015.10.025

Benzie, I. F. F., and Strain, J. J. (1996). The Ferric Reducing Ability of Plasma (FRAP) as a Measure of "Antioxidant Power": the FRAP Assay. Anal. Biochem. 239, 70-76. doi: 10.1006/abio.1996.0292

Chang, C., Dai, R., Leu, Y., and Tsai, T. (2015). Effects of the melanogenic inhibitor, uracil, derived from Lactobacillus plantarum TWK10-fermented soy milk on anti-melanogenesis in B16F0 mouse melanoma cells. J. Funct. Foods 17, 314-327. doi: 10.1016/j.jff.2015.05.022

Cheng, N., Ren, N., Gao, H., Lei, X., Zheng, J., and Cao, W. (2013). Antioxidant and hepatoprotective effects of Schisandra chinensis pollen extract on CCl4induced acute liver damage in mice. Food Chem. Toxicol. 55, 234-240. doi: 10.1016/j.fct.2012.11.022

Chu, Q., Tian, X., Jiang, L., and Ye, J. (2007). Application of capillary electrophoresis to study phenolic profiles of honeybee-collected pollen. J. Agric. Food Chem. 55, 8864-8869. doi: 10.1021/jf071701j

Demirkiran, O., Sabudak, T., Ozturk, M., and Topcu, G. (2013). Antioxidant and tyrosinase inhibitory activities of flavonoids from Trifolium nigrescens Subsp.petrisavi. J. Agric. Food Chem. 61, 12598-12603. doi: 10.1021/jf403 $669 \mathrm{k}$

\section{CONCLUSION}

In this study, we determined total phenolic and flavonoid content and analyzed phenolic acid compositions from FPE and $\mathrm{BPE}$ of rape bee pollen from Yunnan, China. Results showed that phenolics of rape bee pollen are different from previously reported kinds of pollen from various areas. Phenolic extracts of rape bee pollen showed strong antioxidant properties and anti-TYR activity in vitro; activities of free form were higher than those of bound form. FPE reduced melanin content, inhibited activity of TYR, and increased GSG/GSSG in B16 melanoma cells. FPE down-regulated expressions of TYR, TRP1, and TRP-2 through diminution of expression or activation of MITF. Exposure to FPE caused reduction in cAMP levels through down-regulation of MC1R gene expression, which exerts a negative regulatory role in melanogenesis. Therefore, inhibitory melanogenesis activity of FPE is regulated by cAMP/MITF/TYR pathway. FPE of rape bee pollen can be used as a source of natural anti-melanogenesis composition.

\section{AUTHOR CONTRIBUTIONS}

LS and YZhu were involved in the project design, carried out most of the experiments, and drafted the manuscript. YZha participated to extract the phenolic from rape bee pollen and evaluate in vitro antioxidant activity. YG and YZha contributed to the cell experiment and data analysis. All authors read and approved the manuscript finally.

\section{FUNDING}

This study was supported by grants from the National Natural Science Foundation of China (No. 31360381, 31301456).

Dong, J., Gao, K., Wang, K., Xu, X., and Zhang, H. (2015). Cell wall disruption of rape bee pollen treated with combination of protamex hydrolysis and ultrasonication. Food Res. Int. 75, 123-130. doi: 10.1016/j.foodres.2015.05.039

Fanali, C., Dugo, L., and Rocco, A. (2013). Nano-liquid chromatography in nutraceutical analysis: determination of polyphenols in bee pollen. J. Chromatogr. A 1313, 270-274. doi: 10.1016/j.chroma.2013.06.055

Fatiha, B., Didier, H., Naima, G., Khodir, M., Martin, K., Léocadie, K., et al. (2015). Phenolic composition, in vitro antioxidant effects and tyrosinase inhibitory activity of three Algerian Mentha species: M. spicata (L.), M. pulegium (L.) and $M$. rotundifolia (L.) Huds (Lamiaceae). Ind. Crop Prod. 74, 722-730. doi: 10.1016/j.indcrop.2015.04.038

Feás, X., Vázquez-Tato, M. P., Estevinho, L., Seijas, J. A., and Iglesias, A. (2012). Organic bee pollen: botanical origin, nutritional value, bioactive compounds, antioxidant activity and microbiological quality. Molecules 17, 8359-8377. doi: 10.3390/molecules 17078359

Guedes, A. C., Amaro, H. M., Gião, M. S., and Malcata, F. X. (2013). Optimization of ABTS radical cation assay specifically for determination of antioxidant capacity of intracellular extracts of microalgae and cyanobacteria. Food Chem. 138, 638-643. doi: 10.1016/j.foodchem.2012.09.106

Hou, H., Zhao, X., Li, B. F., Zhang, Z. H., and Zhuang, Y. L. (2011). Inhibition of melanogenic activity by gelatin and polypeptides from Pacific cod skin in B16 melanoma cell. J. Food Biochem. 35, 1099-1116. doi: 10.1111/j.1745-4514.2010. 00437.x 
Hu, S., Zheng, Z., Zhang, X., Chen, F., and Wang, M. (2015). Oxyresveratrol and trans-dihydromorin from the twigs of Cudrania tricuspidata as hypopigmenting agents against melanogenesis. J. Funct. Foods 13, 375-383. doi: 10.1016/j.jff.2015.01.010

Kaewnarin, K., Suwannarach, N., Kumla, J., and Lumyong, S. (2016). Phenolic profile of various wild edible mushroom extracts from Thailand and their antioxidant properties, anti-tyrosinase and hyperglycaemic inhibitory activities. J. Funct. Food. 27, 352-364. doi: 10.1016/j.jff.2016.09.008

Kaškonienë, V., Ruoèkuvienë, G., Kaškonas, P., Akuneca, I., and Maruška, A. (2015). Chemometric analysis of bee pollen based on volatile and phenolic compound compositions and antioxidant properties. Food Anal. Method 8, 1150-1163. doi: 10.1007/s12161-014-9996-2

Khatun, A., Rahman, M., Rahman, M. M., Hossain, H., Jahan, I. A., and Nesa, M. L. (2016). Antioxidant, antinociceptive and CNS activities of Viscum orientale and high sensitive quantification of bioactive polyphenols by UPLC. Front. Pharmacol. 7:176. doi: 10.3389/fphar.2016.00176

Kwak, Y. J., Kim, K. S., and Kim, K. M. (2011). Fermented Viola mandshurica inhibits melanogenesis in B16 melanoma cells. Biosci. Biotechnol. Biochem. 75, 841-847. doi: 10.1271/bbb.100641

Lv, H., Wang, X., He, Y., Wang, H., and Suo, Y. (2015). Identification and quantification of flavonoid aglycones in rape bee pollen from Qinghai-Tibetan Plateau by HPLC-DAD-APCI/MS. J. Food Comp. Anal. 38, 49-54. doi: 10.1016/ j.jfca.2014.10.011

Ma, T., Sun, X., Tian, C., Zheng, Y., Zheng, C., and Zhan, J. (2015). Chemical composition and hepatoprotective effects of polyphenols extracted from the stems and leaves of Sphallerocarpus gracilis. J. Funct. Foods 18, 673-683. doi: 10.1016/j.jff.2015.09.001

Mãrghitaş, L. A., Stanciu, O. G., Dezmirean, D. S., Bobiş, O., Popescu, O., Bogdanov, S., et al. (2009). In vitro antioxidant capacity of honeybee-collected pollen of selected floral origin harvested from Romania. Food Chem. 115, 878-883. doi: 10.1016/j.foodchem.2009.01.014

Morais, M., Moreira, L., Feás, X., and Estevinho, L. M. (2011). Honeybee-collected pollen from five portuguese natural parks: palynological origin, phenolic content, antioxidant properties and antimicrobial activity. Food Chem. Toxicol. 49, 1096-1101. doi: 10.1016/j.fct.2011.01.020

Moreira, L., Dias, L. G., Pereira, J. A., and Estevinho, L. (2008). Antioxidant properties, total phenols and pollen analysis of propolis samples from Portugal. Food Chem. Toxicol. 46, 3482-3485. doi: 10.1016/j.fct.2008.08.025

Nardini, M., and Ghiselli, A. (2004). Determination of free and bound phenolic acids in beer. Food Chem. 84, 137-143. doi: 10.1016/S0308-8146(03) 00257-7

Re, R., Pellegrini, N., Proteggente, A., Pannala, A., Yang, M., and Rice-Evans, C. (1999). Antioxidant activity applying an improved ABTS radical cation decolorization assay. Free Radic. Biol. Med. 26, 1231-1237. doi: 10.1016/S08915849(98)00315-3

Sarma, R., Kumari, S., Elancheran, R., Deori, M., and Devi, R. (2016). Polyphenol rich extract of Garcinia pedunculata fruit attenuates the hyperlipidemia induced by high fat diet. Front. Pharmacol. 7:294. doi: 10.3389/fphar.2016. 00294

Shukla, S., Park, J., Kim, D., Hong, S., Lee, J. S., and Kim, M. (2016). Total phenolic content, antioxidant, tyrosinase and $\alpha$-glucosidase inhibitory activities of water soluble extracts of noble starter culture Doenjang, a Korean fermented soybean sauce variety. Food Control. 59, 854-861. doi: 10.1016/j.foodcont.2015. 07.003

Souza, P. M., Elias, S. T., Simeoni, L. A., de Paula, J. E., Gomes, S. M., Guerra, E. N., et al. (2012). Plants from Brazilian Cerrado with potent tyrosinase inhibitory activity. PLoS ONE 7:e48589. doi: 10.1371/journal.pone.0048589
Sun, L., Bai, X., and Zhuang, Y. (2014). Effect of different cooking methods on total phenolic contents and antioxidant activities of four Boletus mushrooms. J. Food Sci. Technol. 51, 3362-3368. doi: 10.1007/s13197-012-0827-4

Tomita, Y. (1992). Melanocyte-stimulating properties of arachidonic acid metabolites: possible role in postinflammatory pigmentation. Pigm. Cell Res. 5, 357-361. doi: 10.1111/j.1600-0749.1992.tb00562.x

Tsuboi, T., and Kondoh, H. (1998). Enhanced melanogenesis induced by tyrosinase gene-transfer increases boron-uptake and killing effect of boron neutron capture therapy for amelanotic melanoma. Pigment Cell Res. 11, 275-282. doi: 10.1111/j.1600-0749.1998.tb00736.x

Ulusoy, E., and Kolayli, S. (2014). Phenolic composition and antioxidant properties of Anzer bee pollen. J. Food Biochem. 38, 73-82. doi: 10.1111/jfbc. 12027

Wang, B., Huang, G., Tai, H., and Huang, M. (2012). Antioxidant and antiinflammatory activities of aqueous extracts of Schizonepeta tenuifolia Briq. Food Chem. Toxicol. 50, 526-531. doi: 10.1016/j.fct.2011.12.010

Wang, B. N., Liu, H. F., Zheng, J. B., Fan, M. T., and Ca, O. W. (2011). Distribution of phenolic acids in different tissues of jujube and their antioxidant activity. J. Agric. Food Chem. 59, 1288-1292. doi: 10.1021/jf103982q

Xiao, J. B. (2015). Dietary flavonoid aglycones and their glycosides: which show better biological significance? Crit. Rev. Food Sci. Nutr. doi: 10.1080/10408398. 2015.1032400 [Epub ahead of print].

Xiao, J. B., Capanoglu, E., Jassbi, A. R., and Miron, A. (2016). Advance on the flavonoid c-glycosides and health benefits. Crit. Rev. Food Sci. Nutr. 56, S29-S45. doi: 10.1080/10408398.2015.1067595

Xiao, J. B., and Högger, P. (2015). Dietary polyphenols and type 2 diabetes: vurrent insights and future perspetcitives. Curr. Med. Chem. 22, 23-38. doi: 10.2174/ 0929867321666140706130807

Xiao, J. B., Ni, X. L., Kai, G. Y., and Chen, X. Q. (2015). Advance in dietary polyphenols as aldose reductases inhibitors: structure-activity relationship aspect. Crit. Rev. Food Sci. Nutr. 55, 16-31. doi: 10.1080/10408398.2011.584252

Zengin, G., Uysal, S., Ceylan, R., and Aktumsek, A. (2015). Phenolic constituent, antioxidative and tyrosinase inhibitory activity of Ornithogalum narbonense L. from Turkey: a phytochemical study. Ind. Crop Prod. 70, 1-6. doi: 10.1016/j. indcrop.2015.03.012

Zhuang, Y., Ma, Q., Guo, Y., and Sun, L. (2017). Protective effects of rambutan (Nephelium lappaceum) peel phenolics on $\mathrm{H} 2 \mathrm{O} 2$-induced oxidantive damages in HepG2 cells and d-galactose-induced aging mice. Food Chem. Toxicol. doi: 10.1016/j.fct.2017.01.022 [Epub ahead of print].

Zhuang, Y., Sun, L., Zhao, X., Wang, J., Hou, H., and Li, B. (2009). Antioxidant and melanogenesis inhibitory activities of collagen peptide from jellyfish (Rhopilema esculentum). J. Sci. Food Agric. 89, 1722-1727. doi: 10.1002/jsfa. 3645

Žilić, S., Vančetović, J., Janković, M., and Maksimović, V. (2014). Chemical composition, bioactive compounds, antioxidant capacity and stability of floral maize (Zea mays L.) pollen. J. Funct. Foods 10, 65-74. doi: 10.1016/j.jff.2014. 05.007

Conflict of Interest Statement: The authors declare that the research was conducted in the absence of any commercial or financial relationships that could be construed as a potential conflict of interest.

Copyright (c) 2017 Sun, Guo, Zhang and Zhuang. This is an open-access article distributed under the terms of the Creative Commons Attribution License (CC BY). The use, distribution or reproduction in other forums is permitted, provided the original author(s) or licensor are credited and that the original publication in this journal is cited, in accordance with accepted academic practice. No use, distribution or reproduction is permitted which does not comply with these terms. 